\title{
Early Childhood Teachers' Self-efficacy and Professional Support Predict Work Engagement
}

\author{
Shannon T. Lipscomb ${ }^{1}$ [D $\cdot$ Kelly D. Chandler ${ }^{2}$. Caitlyn Abshire ${ }^{2} \cdot$ Jamie Jaramillo $^{3} \cdot$ Brianne Kothari $^{1}$
}

Accepted: 22 March 2021 / Published online: 21 April 2021

(c) The Author(s), under exclusive licence to Springer Nature B.V. 2021

\begin{abstract}
Early childhood teachers play a central role in children's learning and development. Yet, they encounter stressors that can negatively impact their well-being, relationships with children, and, ultimately, job retention. To inform efforts to support early childhood teachers' work-related well-being, the current study examines positive factors that predict work engagement. Participants were 50 early childhood teachers from Head Start (34\%), center-based programs (32\%), and licensed home-based programs (34\%). Consistent with a resilience framework and the Job Demands-Resources model, we examined both a personal resource (self-efficacy) and a workplace resource (professional support) in relation to work engagement, or the positive, fulfilling connection to one's work. Teachers' self-efficacy and professional support predicted greater work engagement, accounting for job demands (teachers' compassion fatigue/work distress and children's challenging behaviors) and teachers' education and professional development. Although not causal, findings are suggestive that supporting early childhood teachers with what they need to do their job effectively and feel that they can make meaningful differences in children's lives may help them to engage in their work with passion, dedication, and positive energy. Ultimately, supporting teachers' work engagement may in turn have developmental benefits for children as well.
\end{abstract}

Keywords Work engagement $\cdot$ Early care and education · Self-efficacy $\cdot$ Professional support

\section{Introduction}

High quality early care and education (ECE) programs are widely recognized for their potential to strengthen children's school readiness and development (Reynolds et al., 2017). ECE programs include home- and center-based child care and preschool programs, as well as Head Start and other publicly funded Pre-K programs (Burchinal et al., 2011; Soliday Hong et al., 2015). Early childhood teachers (a term we use as inclusive of providers and teachers across these settings) are fundamental to high quality programs. Young children's interactions and relationships with their teachers underlie many of the developmental benefits of ECE

Shannon T. Lipscomb

Shannon.Lipscomb@osucascades.edu

1 Human Development and Family Sciences, College of Public Health and Human Sciences, Oregon State University Cascades, 1500 SW Chandler Ave, Bend, OR 97702, USA

2 College of Public Health and Human Sciences, Oregon State University, Corvallis, OR, USA

3 Oregon Social Learning Center, Eugene, OR, USA programs (Hatfield et al., 2016). Additionally, positive relationships with early childhood teachers may be especially protective for children experiencing adversity (Lipscomb et al., 2014).

However, teacher turnover, which interferes with teacher-child relationships, is common due to the stress and challenges of this profession (Totenhagen et al., 2016). ECE teachers typically receive low salaries and few benefits (Whitebook et al., 2018). They have little time for planning or professional development, and many experience exhaustion while taking care of large numbers of young children with often complex needs for support (Grant et al., 2019; Totenhagen et al., 2016; Whitebook et al., 2018). At the same time that policy-related research and advocacy focus on turnover and difficult working conditions, many early childhood teachers continue to care for young children with enthusiasm and dedication. Understanding both personal and professional factors that contribute to these positive work outcomes, such as work engagement, is also paramount to efforts to support teachers and the children in their care. The current study examines personal and professional factors 
as predictors of work engagement among early childhood teachers in center-based and home-based programs.

\section{Work Engagement and Its Sequelae}

Work engagement refers to a positive, fulfilling connection to one's work, and represents a dimension of positive work-related well-being (Bakker et al. 2014; Schaufeli et al., 2002). It is defined as, a high level of energy and strong identification with one's work, (Bakker \& Demerouti, 2008, p. 189) and is characterized by three dimensions: vigor, dedication, and absorption. Vigor refers to energy, investment, and persistence, whereas dedication taps into approaches to the work such as pride, involvement, and enthusiasm. Absorption refers to a person's immersion and concentration in the work itself. Some evidence suggests that vigor and dedication represent the core of the work engagement construct, with absorption operating more as a consequence of engagement (González-Romá et al., 2006; Schaufeli et al., 2002).

Work engagement is positively associated with employees' well-being (Schaufeli \& Bakker, 2004) as well as other outcomes for employees, clients, and organizations (Shimazu \& Schaufeli, 2008). Although very few studies have examined work engagement among preschool teachers (Nislin et al., 2016; Tayama et al., 2018), patterns of evidence emerge by triangulating these studies with investigations of work engagement among teachers in elementary (Burić \& Macuka, 2018; Pepe et al., 2019), secondary (Abos et al., 2018; Arora \& Dhiman, 2018), and special education settings (Minghui et al. 2018). Work engagement is emerging as a predictor of intent to continue working in the field (Tayama et al., 2018) as well as job satisfaction and organizational citizenship behavior (Arora \& Dhiman, 2018). Of particular note, in a study of over 1000 preschool teachers in Japan, work engagement was the only factor predicting intent to continue working in both younger (under 39 years) and older (over 40 years) teachers (Tayama et al., 2018). Beyond commitment and retention-related outcomes, work engagement is also associated with teachers' emotional health and well-being (Burić \& Macuka, 2018; Pepe et al., 2019). Identifying factors that contribute to work engagement among early childhood teachers is emerging as a focus of research and may be imperative to increase retention, teacher well-being, and quality interactions that support children's development. The current study examines predictors of work engagement among early childhood teachers that are shared across home-based (often one or two teachers caring for children of varying ages in a home) and center-based programs (typically with multiple classrooms, teachers, assistants, and administrators). The study examines teachers' experiences of both personal and professional factors that are relevant across settings as predictors of work engagement. This work complements more in-depth organizational-level assessments of policies and practices specific to center-based ECE programs (e.g., SEQUEL; Whitebook et al., 2016).

\section{Conceptual Frameworks}

To investigate these personal and professional protective factors the current study applies a resilience framework and the Job Demands-Resources (JD-R) model (Bakker $\&$ Demerouti, 2007). Resilience presents a useful framework for investigating work engagement as an indicator of work-related well-being. Resilience is a dynamic process of positive adaptation to adversity that unfolds within socioecological contexts (Liu et al., 2017; Masten, 2018). Within contexts such as work environments, protective factors of individuals, relationships, and communities support positive adaptation in the face of adversity (Development Services Group, 2013; Ungar \& Liebenberg, 2011). Britt et al. (2016) applied a resilience framework to the workplace where adversity is comprised of exposure to significant, intense, chronic stressors (e.g., physical demands, long hours). Employee resilience, or positive adaptation to adversity in the workplace, is evident by healthy relationships, positive well-being, and high job performance (Britt et al., 2016). As such, early childhood teachers who have stronger protective factors may adapt more positively at work (indicated by work engagement) when they face challenging circumstances. This study examines personal and professional protective factors as predictors of work engagement.

Consistent with a resilience framework, there is some indication that job resources may buffer some of the effects of job demands on burnout (Bakker et al., 2005). The JD-R model is widely used to examine how both situational (e.g., professional or workplace) and individual (personal) factors affect employee well-being across a broad range of occupations (Bakker et al., 2014). Of particular relevance to the current study, the JD-R model sets up a strengths-based investigation in which protective factors (job resources such as autonomy and support) predict positive outcomes (work engagement), while accounting for job demands (such as high workload, physical demands, and emotional labor) which contribute more directly to burnout (Bakker et al., 2014; Hultell et al., 2011).

The JD-R model may also offer an important framework for strengthening understanding of the early childhood workforce. Instead of focusing on burnout, a negative outcome resulting from high job demands and low resources, examining factors related to work engagement, a positive outcome, takes a strengths-based approach to inform interventions that support early childhood teachers' wellbeing and performance at work. The JD-R model and related conceptual 
models (e.g., Christian et al., 2011) highlight the importance of understanding work engagement because it serves as a key mediating mechanism linking job resources and demands with outcomes, such as retention, which is imperative to understand and improve in the early childhood field. Moreover, the JD-R model is advantageous to research conducted with home- and center-based early childhood teachers in the same study because it offers a general framework for conceptualizing job demands and resources rather than different measures for different types of programs.

Little empirical evidence is available about the factors that contribute to work engagement, specifically among early childhood teachers. In other professions, both professional (e.g., workplace) and personal resources have emerged as important predictors of work engagement. More specifically, job resources, such as autonomy (Bakker et al., 2008), social support, and supervisory feedback (Bakker et al., 2008; Schaufeli \& Bakker, 2004) predict work engagement across multiple client-focused professions (e.g., teachers, dentists, home-care employees). Moreover, personal resources (e.g., optimism, self-efficacy, self-esteem) also appear to be important to work engagement across professions (Bakker et al., 2008). Furthermore, both the resilience framework and the JD-R model suggest that it will be important to consider factors both of individual teachers and of their support at work (i.e., personal and workplace resources).

This study focuses in on two resources that have strong support for inclusion in an initial study of work engagement among early childhood teachers: self-efficacy as a personal resource, and professional supports as a workplace resource. These resources may be more malleable through workplace interventions than structural resources such as compensation, which is addressed in a related body of work (e.g., Whitebook et al., 2018). In the current study, we acknowledge the role of stressors and job demands, which are more often linked with burnout (Bakker \& Demerouti, 2007; Hakanen et al., 2006; Hultell \& Gustavsson, 2011; Schaufeli \& Bakker, 2004), while taking a strengths-based approach by focusing on the links between resources and work engagement among early childhood teachers.

\section{Personal and Professional Job Resources Contributing to Work Engagement}

\section{Self-efficacy}

Self-efficacy refers to individuals' perceptions that they can competently meet demands in a given context and may therefore be an important personal resource that contributes to work engagement. Indeed, Xanthopoulou et al. (2007) found that self-efficacy was a significant factor of employees' personal resources, which was positively associated with work engagement. Specifically within the teaching field, self-efficacy represents teachers' beliefs and perceptions about their teaching abilities and the extent to which they can impact positive change with children (Tschannen-Moran et al., 1998). There is some evidence to suggest that teachers' self-efficacy promotes work engagement. For example, in a study of 2569 teachers from 127 Norwegian elementary and middle schools, self-efficacy positively predicted both work engagement and job satisfaction (Skaalvik \& Skaalvik, 2014). Other studies document links between teachers' selfefficacy and commitment to teaching (a concept related to work engagement; Klassen \& Chiu, 2011; Klassen et al., 2013).

Although very little is known about associations between teaching self-efficacy and work engagement among early childhood teachers, a qualitative study of 63 early childhood teachers in Australia identified self-efficacy as a key contributor to teachers' commitment to continuing to work as a teacher (Kilgallon et al., 2008). Guo et al. (2011) also documented associations between preschool teachers' selfefficacy and their sense of community at work. Moreover, initial evidence suggests that early childhood teachers' selfefficacy is malleable and can be strengthened through preparation, effective professional development, and support from leaders (Ciyer et al., 2010; Pas et al., 2012; Von Suchodoletz et al., 2018). Thus, it may be particularly important to examine how self-efficacy may help early childhood teachers to engage in their work with dedication, vigor, and absorption.

\section{Professional Supports}

Although workplace resources that contribute specifically to early childhood teachers' work engagement have not yet been examined, teachers have clearly articulated that working conditions affect their ability to effectively do their jobs (Irvine et al., 2016; Whitebook et al., 2016). In addition to policies related to wages, benefits, and time for planning or professional development including mentoring, which are difficult to equate across center- and home-based settings, there is growing evidence that a general feeling of professional support may be of central importance to work engagement. The sources of support may vary, but the underlying construct is a teachers' feeling that they have the support they need to be effective. For example, Minghui et al. (2018) found that special education teachers with more perceived social support reported more positive work engagement. Additionally, a study of over 2000 Finish primary, secondary, and vocational teachers found that job resources, including professional support from supervisors when needed, predicted greater work engagement (Hakanen et al., 2006).

Additionally, prior research among preschool teachers indicates that those who have a stronger sense of community at work experience more job satisfaction and commitment 
to their careers (Collie et al., 2011; McGinty et al., 2008), tend to engage in more professional development (Wagner \& French, 2010), and provide higher quality care to children (McGinty et al., 2008). In their qualitative work with early childhood teachers in Australia, Kilgallon et al. (2008) found that professional support from colleagues and mentors contributes to job satisfaction and motivation. Findings from a study in the United States indicate that the inclusion of a reflective individual discussion with the instructor in professional learning protected teachers from emotional exhaustion, a component of burnout (Roberts et al., 2020). In Brisbane, findings from the National Early Care and Education Workforce Development Policy Workshop point to mentorship and learning communities of practice as effective supports for the workforce overall, and to support from directors such as breaks, appreciation and support in difficult situations as specifically helpful to younger workers (Irvine et al., 2016). Hence, the current study examines early childhood teachers' perception of professional support as a job resource that may be important to their work engagement, while accounting for their professional development activities.

\section{Accounting for Early Childhood Teachers' Job Demands}

When studying associations between resources and positive aspects of work well-being such as engagement, it is important to account for teachers' experiences of job demands and stressors. Although the JD-R model posits that job demands predict burnout while job resources are linked with work engagement (Bakker et al., 2014), this model has not yet been studied with early childhood teachers. However, two demands may be particularly important to account for among early childhood teachers: distress and child behavior. Prior research suggests stress and burnout interfere with teacher-child relationships (Whitaker et al., 2015; Yoon, 2002) and affect children's stress system activation (Oberle \& Schonert-Reichl, 2016). Teachers' stress may serve as a marker for a host of challenges they experience related to work, which in turn may affect their work engagement. In particular, prior research indicates the importance of accounting for psychological distress and/or compassion fatigue in studies of work-related outcomes among human service professionals (Adams et al., 2006; Cole et al., 2014).

Children's challenging behaviors are another specific job demand reported by early childhood teachers. Behaviors such as aggression, defiance, and inattention pose difficulties for teachers as well as children. Children's challenging behaviors appear to negatively impact teachers' job satisfaction (Bullough et al., 2012) as well as caregiving and children's learning (NICHD, 2005; Vandell et al., 2010).
Evidence from additional research conducted in elementary and secondary schools affirms that student misbehavior and discipline problems are key sources of teacher stress and burnout (Hastings \& Bham, 2003; Kokkinos, 2007; Tsouloupas et al., 2010).

When considering how children's behaviors affect their teachers, it is important to measure teachers' perceptions of children's behavior because up to $30 \%$ of the variance in teacher ratings of preschool children's behavior can be attributed to teacher perception (Mashburn et al., 2006). Thus, the current study accounts for early childhood teachers' ratings of children's behavior when examining associations between personal (self-efficacy) and job (professional supports) resources and their work engagement.

\section{Current Study}

In light of a pressing need to support early childhood teachers in their important work with young children, the current study examines both a personal and a workplace resource in relation to work engagement. Work engagement is not yet understood among early childhood teachers, whose lives and impacts in society may greatly benefit from increased knowledge of work-related well-being. A resilience framework (Lui et al., 2017; Masten, 2018) and the Job Demands and Resources Model (JD-R; Bakker \& Demerouti, 2007) provide a theoretical rationale for examining both personal and professional resources as predictors of work engagement. Prior research identifies self-efficacy and professional supports as important resources for early childhood teachers (Collie et al., 2011; Kilgallon et al., 2008; Tschannen-Moran et al., 1998) that the current study examines in relation to work engagement. Given prior evidence that children's behavior and teacher stress and/or compassion fatigue can pose challenges (Adams et al., 2006; Bullough et al., 2012; Cole et al., 2014), the current study also accounts for these factors. We hypothesized that teachers' self-efficacy and professional support will predict unique variance in their work engagement, while accounting for children's behaviors, work stress, and teachers' education and professional development.

\section{Method}

\section{Participants}

The sample consisted of 50 early childhood teachers from Head Start (34\%), center-based (32\%), and licensed homebased $(34 \%)$ programs. Teachers were selected to participate in this study because of their interest in a professional development program on promoting resilience with children 
impacted by trauma. This study utilizes data collected at baseline, prior to teachers' participation in the professional development program. Teachers held the following positions: $60 \%$ lead teacher, $16 \%$ assistant teacher, $8 \%$ aid, $20 \%$ director, and $2 \%$ other ( $8 \%$ had more than one position). Most identified as female (96\%) and White (88\% White only; $4 \%$ White and another race/ethnicity). Other race/ethnicities represented include Latino/Hispanic (6\%), Native American (2\%), Black/African American (2\%), and Native Hawaiian/ Pacific Islander (2\%). All identified English as their primary language. Their highest level of education included high school (8.2\%), some college (20.4\%), associates' or bachelor's degree $(59.2 \%)$, and graduate degree $(12.2 \%)$. The majority of participants had been teaching at their current early childhood program for 3 years or fewer $(63.2 \%)$.

\section{Procedures}

Teachers completed an online survey prior to participation in a new professional development program focused on resilience and trauma (Lipscomb et al., 2021). Recruitment took place in a region of the Pacific Northwest, and occurred through outreach to ECE programs, and then to their teachers. Teachers working in licensed ECE programs in this area are required to attain a minimum of $15 \mathrm{~h}$ of continuing education annually. Teachers opted to participate in this study because they desired professional development and support related to early childhood trauma. This research was conducted in accordance with American Psychological Association guidelines: Informed consent was obtained from participants and the study was approved by the authors' Institutional Review Board. All data for the current study were collected at baseline, prior to participation in the professional development program. The authors declare that they have no conflict of interest.

\section{Measures}

\section{Work Engagement}

Teachers completed the Utrecht Work Engagement Scale (UWES; Schaufeli \& Bakker, 2004; Schaufeli et al., 2002). This scale includes 17 items to measure vigor (e.g., "At my work, I feel bursting with energy"), dedication (e.g., "I find my work full of meaning and purpose" and "I am proud of the work that I do"), and absorption (e.g., "Time flies when I'm working"). Response options range from 1 (never) to 6 (always/everyday). The 17 items were averaged in the total work engagement score (Cronbach's alpha $=0.83$ ), with higher scores indicating greater work engagement.

\section{Teaching Self-efficacy}

Teachers completed the Teacher Self-efficacy Short Form (TSE; Tschannen-Moran \& Hoy, 2001), measuring a teacher's sense of self-efficacy related to dealing with classroom challenges. Each of the 16 items asks teachers to indicate how much they can do to overcome various classroom difficulties. Example items include, "Get through to the most difficult children" and "Help your children think critically." Response options ranged from 1 (nothing) to 6 (a great deal). Items were averaged (Cronbach's alpha $=0.92$ ).

\section{Professional Support}

One global item was used to represent teachers' feelings of professional support, "Our program provides me with the professional support I need to do my job most effectively." Response options ranged from 1 (strongly disagree) to 4 (strongly agree).

\section{Child Classroom Behavior}

Teachers responded to 1 item about classroom behavior: "At this point, how would you rate the behavior of children in your group/class?" (Von Suchodeltz et al., 2018). Response options ranged from 1 (This group behaves exceptionally well) to 5 (The group very frequently has behavioral challenges and is almost always difficult to handle).

\section{Compassion Fatigue/Distress}

Teachers completed a 13-item measure of Compassion Fatigue and Psychological Distress related to work (Adams et al., 2006). Each item asks about the frequency of thoughts and feelings at work with response options ranging from 1 (never/rarely) to 6 (very often). Example items include, "I have felt trapped by my work" and "It's hard to stop thinking about an especially difficult child." Items were averaged $($ Cronbach's alpha $=0.84)$.

\section{Covariates}

Teacher education and professional development were included as covariates in the analysis. Teacher education was measured by responses to the question, "What is the highest level of education that you have ever completed?" Response options ranged from 1 (8th grade or less) to 9 (Graduate degree). Teacher professional development was measured by teacher responses to whether they had professional development in the previous year related to eight different areas, coded as 1 for "Yes" and 0 for "No" to each item. Example items include "Supporting children's mental health/social emotional development," "Skills and 
activities for teaching early literacy," and "Caring for children who experience trauma or other serious adversities." The eight items were summed (Cronbach's alpha $=0.87$ ).

\section{Results}

\section{Preliminary Analyses}

On average, teachers' ratings of work engagement were high $(M=5.73)$, with ample variability (Table 1$)$. A first step in developing the analytic model was to identify possible variation in work engagement and/or predictor variables by setting (i.e., Head Start, center-based, and homebased). Results from Analysis of Variance (ANOVA) tests revealed that only two covariates varied by setting: teachers' education level $F(2,46)=3.18, p=0.05)$ and professional development $F(2,46)=21.30, p<0.001)$. Tukey's post hoc analyses indicated that the education level of Head Start teachers was significantly higher $(M=7.47, S D=1.23)$ than home-based teachers $(M=6.19$, $S D=1.56$ ). Similarly, the number of professional development experiences of Head Start teachers was significantly higher $(M=7.41, S D=1.27)$ than center-based teachers $(M=3.00, S D=2.10)$ and home-based teachers $(M=3.71$, $S D=2.64)$. Because none of the primary study variables differed by setting type, and because the sample size is small, setting type was not included in further analysis.

Table 1 shows correlations among study variables. Work engagement was moderately-to-strongly correlated with self-efficacy and professional support in a positive direction, and with children's behavior challenges in a negative direction. Additionally, children's behavioral challenges were negatively correlated with both self-efficacy $(r=-0.32, p<0.05)$ and professional support $(r=-0.41$, $p<0.01)$. Self-efficacy and professional support were also positively correlated $(r=0.39, p<0.01)$.

\section{Hypothesis Testing}

All analyses were completed in STATA Version 14 (StataCorp, 2015). Full information maximum likelihood (FIML) methods were used to address missing data. A three-step hierarchical linear regression was conducted predicting teacher work engagement. Teacher education level and professional development were entered as covariates at step 1 (Model 1); children's behaviors and compassion fatigue/ distress were entered at step 2 (Model 2). Finally, teacher's self-efficacy and professional support were entered at step 3 (Model 3).

Results are displayed in Table 2. Consistent with our hypothesis, both of the job resources (self-efficacy and professional supports) significantly and positively predicted teacher work engagement. Additionally, one of the job demands (child behaviors) significantly and negatively predicted teacher work engagement, controlling for other variables. Teacher work compassion fatigue/distress did not significantly predict work engagement. Model 3 , with all variables included, predicted $55 \%$ of the variance in work engagement.

\section{Discussion}

The current study examined work engagement, a positive dimension of work-related well-being, among early childhood teachers who care for children across a variety of home- and center-based settings. Informed by a resilience framework (Lui et al., 2017; Masten, 2018) and the Job Demands and Resources (JD-R) model (Bakker \& Demerouti, 2007), we examined two resources including both a personal factor (self-efficacy) and a workplace resource (teachers' impressions of professional support). Findings supported the hypothesis: both teachers' self-efficacy and their professional supports predicted greater work engagement, while accounting for children's challenging behaviors, compassion fatigue/work distress, education level, and

Table 1 Correlations and descriptive statistics for key study variables

\begin{tabular}{|c|c|c|c|c|c|c|c|c|c|c|c|}
\hline Variable & 1 & 2 & 3 & 4 & 5 & 6 & 7 & Min & Max & $M$ & $S D$ \\
\hline 1. Work engagement & & & & & & & & 3.94 & 6.71 & 5.73 & 0.62 \\
\hline 2. Education & -0.08 & & & & & & & 4.00 & 9.00 & 6.92 & 1.55 \\
\hline 3. Professional development & 0.25 & 0.24 & & & & & & 0.00 & 8.00 & 4.78 & 2.83 \\
\hline 4. Children's challenging behavior & $-0.55 * *$ & 0.18 & -0.13 & & & & & 1.00 & 5.00 & 3.48 & 0.71 \\
\hline 5. Compassion fatigue & -0.13 & 0.28 & -0.06 & 0.00 & & & & 1.00 & 4.69 & 2.25 & 1.10 \\
\hline 6. Self-efficacy & $0.51 * *$ & $-0.39 * *$ & 0.01 & $-0.32 *$ & 0.06 & & & 4.00 & 6.00 & 5.12 & 0.56 \\
\hline 7. Professional support & $0.52 * *$ & -0.11 & 0.08 & $-0.41 * *$ & -0.12 & $0.39 * *$ & & 2.00 & 4.00 & 3.45 & 0.65 \\
\hline
\end{tabular}

$* p<0.05, * * p<0.01$ 
Table 2 Hierarchical regression results: predictors of teacher work engagement $(\mathrm{N}=50)$

\begin{tabular}{|c|c|c|c|c|c|c|}
\hline \multirow[t]{3}{*}{ Variable } & \multicolumn{2}{|l|}{ Model 1} & \multicolumn{2}{|l|}{ Model 2} & \multicolumn{2}{|l|}{ Model 3} \\
\hline & \multicolumn{2}{|c|}{ Work engagement } & \multicolumn{2}{|c|}{ Work engagement } & \multicolumn{2}{|c|}{ Work engagement } \\
\hline & $B(S E)$ & $\beta$ & $B(S E)$ & $\beta$ & $B(S E)$ & $\beta$ \\
\hline Constant & $5.83(0.39)^{*}$ & & $6.84(0.40) *$ & & $3.13(0.89)^{*}$ & \\
\hline Education & $-0.06(0.06)$ & -0.14 & $0.00(0.05)$ & 0.01 & $0.07(0.05)$ & 0.17 \\
\hline Professional development & $0.06(0.03)$ & $0.29^{+}$ & $0.04(0.03)$ & 0.18 & $0.03(0.02)$ & 0.15 \\
\hline Challenging behavior & & & $-0.46(0.10)$ & $-.53 * *$ & $-0.30(0.10)$ & $-0.31 * *$ \\
\hline Compassion fatigue & & & $-0.07(0.07)$ & -0.12 & $-0.08(0.06)$ & -0.15 \\
\hline Self-efficacy & & & & & $0.40(0.13)$ & $0.40^{* *}$ \\
\hline Professional support & & & & & $0.24(0.11)$ & $0.30 *$ \\
\hline$R^{2}$ & 0.08 & & 0.35 & & 0.55 & \\
\hline$F$ for change in $R^{2}$ & 2.21 & & $8.36 * *$ & & $8.75 * *$ & \\
\hline
\end{tabular}

${ }^{+} p<0.10, * p<0.05, * * p<0.01$ professional development attended in the past year. This study provides an important foundation for future research to deepen our understanding of potentially malleable factors that support early childhood teachers to engage in their important and often challenging work with dedication and passion.

\section{Work Engagement Among Early Childhood Teachers}

This is the first study of which we are aware to utilize the Work Engagement Scale (UWES; Schaufeli \& Bakker, 2004; Schaufeli et al., 2002) with early childhood teachers in the United States. The 17-item scale showed good internal consistency. Teachers reported high mean scores on work engagement, with meaningful variation across individuals, but no significant differences by setting type (home-based versus Head Start or other center-based programs). These findings provide initial evidence of the utility of studying work engagement in a variety of ECE settings; future research with larger samples should examine psychometric properties of the measure within each type of care and examine measurement invariance of the construct itself.

Given that related fields have found the Work Engagement Scale useful to the study of work-related well-being, the early childhood field may benefit from additional research on malleable factors that contribute to work engagement. The presence of a special issue dedicated to research on the well-being of early childhood teachers (see Hindman \& Bustamante, 2019) is an indicator of increasing attention to this issue. However, much of this research continues to focus on threats to well-being (e.g., depression, stress) rather than on contributors to positive aspects of well-being, such as engagement. The current study offers a platform for additional research on work engagement as an important part of the growing body of literature on teacher well-being, as well as environmental conditions (e.g., Whitebook et al., 2016, 2018) that affect well-being, and its implications for children and families.

\section{Job Resources Predicting Work Engagement}

Consistent with the JD-R model (Bakker \& Demerouti, 2007), and with prior research conducted with teachers of older children (Mingui, 2018; Skaalvik \& Skaalvik, 2014), early childhood teachers who reported more personal and professional resources also exhibited greater engagement in their work. This finding extends prior research, suggesting that the associations between self-efficacy and work engagement that have been documented among elementary and middle school teachers (Skaalvik \& Skaalvik, 2014) also apply to teachers working with preschool-aged children within a variety of ECE settings. This body of evidence shows that teachers who believe that they can effectively support children's learning and development report engaging in their work with a more positive motivational state characterized by dedication, vigor, and absorption. Given that self-efficacy also predicts teachers' commitment to teaching (Kilgallon et al., 2008; Klassen \& Chiu, 2011; Klassen et al., 2013), and that work engagement predicts intent to continue working as a preschool teacher (Tayama et al., 2018), self-efficacy may emerge as a particularly important personal resource that supports teachers to continue working with enthusiasm and dedication to their work with young children.

Moreover, in addition to the effect of self-efficacy on engagement, teachers' reports of having the supports they need to do their job effectively predicted unique variance in their work engagement. Teachers' global reports (one survey item) of support may serve as a marker for a wide 
variety of supports that may differ by individual teacher. While some teachers may need more health or safety supports, others need emotional support or training; the underlying concept is teachers' feelings of having the support they need. Findings from the present study provide initial evidence that when they do feel supported to do their job, even in a global sense, they report more vigor, dedication, and absorption in their work with young children. This finding, coupled with evidence from related professions linking job resources and work engagement (e.g., Bakker et al., 2014), helps advance understanding of work engagement as a facet of positive work-related well-being. Findings not only extend prior work to early childhood teachers, but also add that personal and professional resources may contribute uniquely. This focus on work engagement as a positive facet of work-related well-being complements research on working conditions (e.g., Whitebook et al., 2018) and threats to well-being (e.g., Roberts et al., 2019) among early childhood teachers. Future research should bring these related lines of research together more intentionally, such as through studying individual teachers' work engagement as a mediator between organizational-level working conditions and positive outcomes such as teachers' physical health, retention and/or quality interactions with children.

Although this study focused on positive factors, or resources, associated with engagement, findings also revealed that teachers' perceptions of children's challenging behavior contribute negatively to their work engagement, even when accounting for resources, work stress and compassion fatigue, professional development, and education level. This suggests that children's challenging behavior may be a particularly important job demand to better understand. In the current study, children's behavior was measured by teachers' report of children in their classroom overall; future research may investigate the importance of teachers' perceptions of more specific types of behaviors, or their attributions of the reasons behind children's behaviors.

\section{Foundation for Future Research}

Within a resilience framework (Masten, 2018), it will be important for future research to examine the extent to which resources, such as self-efficacy and professional supports, help to buffer teachers from their experiences with job demands, such as challenging behavior, poor compensation, or large group sizes or ratios of children to teachers, on their work engagement. Furthermore, future research should explore the processes that teachers use to cope with adversity in the workplace and the processes that promote positive adaptation (Britt et al., 2016). Given that not all job demands can be eliminated or reduced, it is important to consider how to support teachers' resilience.
Moreover, supporting teachers' work-related well-being and resilience could have important implications for children's educational resilience. Educational resilience, the increased likelihood of academic success despite adverse conditions, is nurtured in part by students' relationships with their teachers (Schroeter et al., 2015; Strolin-Goltzman et al., 2016). Young people who have experienced adversity have identified positive relationships with adults as the most powerful influences on their educational success (StrolinGoltzman et al., 2016). Since teacher stress and burnout can hinder teacher-child relationships (Whitaker et al., 2015; Yoon, 2002), supporting teachers' work-related well-being may be important to children's educational resilience.

Another extension from the current research will be to examine the effects of participation in professional support programs, such as coaching or increased knowledge from trainings or coursework, on teachers' feelings of being supported and efficacious at work. Initial evidence indicates that coaching may support increases in preschool teachers' selfefficacy (Von Suchodeletz et al., 2018). Interventions that increase these types of personal or professional resources may be able to help strengthen teachers' dedication, enthusiasm and investment in their work, all important aspects of work engagement.

Moreover, recognizing that the study of job resources among early childhood teachers is emerging, future work is needed to operationalize and measure job resources, as well as job demands in the early childhood field. It will be important for this work to clarify the aspects of resources that may be common to teachers working in various home- and center-based programs as well as those specific to certain types of settings. While regulations, standards, and professional development opportunities often differ by setting type, efforts to create more inclusive and diverse early childhood systems also require knowledge of the processes and experiences that are shared by teachers working in various settings.

\section{Limitations and Strengths of the Current Study}

The current study's inclusion of teachers working in a variety of early learning settings, such as home-based care, centers, and Head Start programs is an important strength. Additionally, accounting for children's challenging behavior and teachers' compassion fatigue/distress, as well as other covariates, increases confidence in the unique effects of selfefficacy and professional supports on work engagement.

Yet, the current study has a number of limitations that will be important to address in future research. The sample size was small and lacked diversity with respect to race, ethnicity, language, and gender. The cross-sectional design precludes identification of causal links; it could be that 
being more engaged in one's work contributes to self-efficacy and feelings of support at work. Moreover, teachers' reports of professional supports were measured with only one item, as were their impressions of children's behavior. Shared method variance (all measures were reported by teachers) likely contributes to some of the variance in the work engagement outcome that is attributed to the predictor variables of self-efficacy and professional supports. Although it would be difficult to measure constructs such as self-efficacy and feelings of support without self-report, in future research these measures could be complemented by another informant's report of professional resources, and/or with objective measures of demands such as children's challenging behaviors or child-teacher ratios. Moreover, the current study could have been strengthened by inclusion of teachers' total years of experience, which is not yet understood in relation to work engagement among early childhood teachers.

\section{Conclusion}

Work engagement represents a positive work-related outcome that has implications for teachers' retention and well-being (Burić \& Macuka, 2018; Pepe et al., 2019; Tayama et al., 2018) and therefore warrants further investigation. Findings suggest that supporting early childhood teachers to have what they need to do their job effectively and feel that they can make meaningful difference in young children's lives may help teachers to engage in their work with passion, dedication, and positive energy. Given the central role that early childhood teachers play in the lives of the young children they care for (Hatfield et al., 2016; Lipscomb et al., 2014), supporting teachers' engagement in their work may ultimately have developmental benefits for children as well as for teachers.

Funding The research reported here was supported by the Institute of Education Sciences, U.S. Department of Education, through Grant R305A150107 to Oregon State University. The opinions expressed are those of the authors and do not represent views of the Institute or the U.S. Department of Education. The funder was not involved in the study design, nor in the collection, analysis, interpretation or reporting of the findings.

\section{Declarations}

Conflict of interest The authors have no conflicts of interest to declare.

Ethical Approval This research was conducted in accordance with American Psychological Association guidelines: Informed consent was obtained from participants and the study was approved by the first author's Institutional Review Board.

\section{References}

Abos, A., Sevil, J., Martin-Albo, J., Aibar, A., \& Garcia-Gonzalez, L. (2018). Validation evidence of the Motivation for Teaching Scale in secondary education. The Spanish Journal of Psychology, 21(e19), 1-12. https://doi.org/10.1017/sjp.2018.11

Adams, R. E., Boscarino, J. A., \& Figley, C. R. (2006). Compassion fatigue and psychological distress among social workers: A validation study. The American Journal of Orthopsychiatry, 76(1), 103-108. https://doi.org/10.1037/0002-9432.76.1.103

Arora, N., \& Dhiman, N. (2018). Role of work engagement in predicting organizational citizenship behaviour among school teachers. Gurukil Business Review (GBR), 14, 42-46

Bakker, A. B. (2011). An evidence-based model of work engagement. Current Directions in Psychological Science, 20(4), 265-269. https://doi.org/10.1177/0963721411414534

Bakker, A. B., \& Demerouti, E. (2007). The job demands-resources model: State of the art. Journal of Managerial Psychology, 22(3), 309-328. https://doi.org/10.1108/02683940710733115

Bakker, A. B., \& Demerouti, E. (2008). Towards a model of work engagement. Career Development International, 13(3), 209223. https://doi.org/10.1108/13620430810870476

Bakker, A. B., Demerouti, E., \& Euwema, M. C. (2005). Job resources buffer the impact of job demands on burnout. Journal of Occupational Health Psychology, 10(2), 170-180. https://doi. org/10.1037/1076-8998.10.2.170

Bakker, A. B., Demerouti, E., \& Sanz-Vergel, A. I. (2014). Burnout and work engagement: The JD-R approach. Annual Review of Organizational Psychology and Organizational Behavior, 1(1), 389-411. https://doi.org/10.1146/annurev-orgps ych-031413-091235

Bakker, A. B., Schaufeli, W. B., Leiter, M. P., \& Taris, T. W. (2008). Work engagement: An emerging concept in occupational health psychology. Work \& Stress, 22(3), 187-200. https://doi.org/10. 1080/02678370802393649

Britt, T. W., Shen, W., Sinclair, R. R., Grossman, M. R., \& Klieger, D. M. (2016). How much do we really know about employee resilience? Industrial and Organizational Psychology, 9(2), 378-404. https://doi.org/10.1017/iop.2015.107

Bullough, R. V., Hall-Kenyon, K. M., \& MacKay, K. L. (2012). Head start teacher well-being: Implications for policy and practice. Early Childhood Education Journal, 40(6), 323-331. https:// doi.org/10.1007/s10643-012-0535-8

Burchinal, M., Kainz, K., \& Cai, Y. (2011). How well do our measures of quality predict child outcomes? A meta-analysis and coordinated analysis of data from large-scale studies of early childhood settings. In M. Zaslow, I. Martinez-Beck, K. Tout, \& T. Halle (Eds.), Quality measurement in early childhood settings. (pp. 11-31). Paul H Brookes Publishing.

Burić, I., \& Macuka, I. (2018). Self-efficacy, emotions and work engagement among teachers: A two wave cross-lagged analysis. Journal of Happiness Studies, 19(7), 1917-1933. https://doi. org/10.1007/s 10902-017-9903-9

Christian, M. S., Garza, A. S., \& Slaughter, J. E. (2011). Work engagement: A quantitative review and test of its relations with task and contextual performance. Personnel Psychology, 64(1), 89-136. https://doi.org/10.1111/j.1744-6570.2010.01203.x

Ciyer, A., Nagasawa, M., Swadener, B. B., \& Patet, P. (2010). Impacts of the Arizona System Ready/Child Ready professional development project on preschool teachers' self-efficacy. Journal of Early Childhood Teacher Education, 31, 129-145. https:// doi.org/10.1080/10901021003781197

Cole, R., Craigen, L., \& Cowan, R. (2014). Compassion fatigue in human service practitioners. Journal of Human Services, 34(1), 117-120. 
Collie, R. J., Shapka, J. D., \& Perry, N. E. (2011). Predicting teacher commitment: The impact of school climate and social-emotional learning. Psychology in the Schools, 48(10), 1034-1048. https:// doi.org/10.1002/pits.20611

Development Services Group. (2013). Protective factors for populations served by the Administration on Children, Youth, and Families. A literature review and theoretical framework: Executive summary. Retrieved from https://dsgonline.com/acyf/DSG\% 20Protective\%20Factors\%20Literature\%20Review\%202013\% 20Exec\%20Summary.pdf

Early Child Care Research Network, N. I. C. H. D. (Ed.). (2005). Child care and child development: Results from the NICHD Study of Early Child Care and Youth Development. Guilford Press.

González-Romá, V., Schaufeli, W. B., Bakker, A. B., \& Lloret, S. (2006). Burnout and work engagement: Independent factors or opposite poles? Journal of Vocational Behavior, 68(1), 165-174. https://doi.org/10.1016/j.jvb.2005.01.003

Grant, A. A., Jeon, L., \& Buettner, C. K. (2019). Relating early childhood teachers' working conditions and well-being to their turnover intentions. Educational Psychology, 39, 294-312. https://doi. org/10.1080/01443410.2018.1543856

Guo, Y., Justice, L. M., Sawyer, B., \& Tompkins, V. (2011). Exploring factors related to preschool teachers' self-efficacy. Teaching and Teacher Education, 27, 961-968. https://doi.org/10.1016/j.tate. 2011.03.008

Hakanen, J. J., Bakker, A. B., \& Schaufeli, W. B. (2006). Burnout and work engagement among teachers. Journal of School Psychology, 43(6), 495-513. https://doi.org/10.1016/j.jsp.2005.11.001

Hastings, R. P., \& Bham, M. S. (2003). The relationship between student behaviour patterns and teacher burnout. School Psychology International, 24(1), 115-127. https://doi.org/10.1177/01430 34303024001905

Hatfield, B. E., Burchinal, M. R., Pianta, R. C., \& Sideris, J. (2016). Thresholds in the association between quality of teacher-child interactions and preschool children's school readiness skills. Early Childhood Research Quarterly, 36, 561-571. https://doi.org/10. 1016/j.ecresq.2015.09.005

Hindman, A. H., \& Bustamante, A. S. (2019). Understanding wellbeing among teachers in early childhood settings: Challenges, supports, and implications for children's development. Journal of Applied Developmental Psychology, 61, 1-3. https://doi.org/ 10.1016/j.appdev.2019.03.005

Hultell, D., \& Gustavsson, J. P. (2011). Factors affecting burnout and work engagement in teachers when entering employment. Work, 40(1), 85-98. https://doi.org/10.3233/WOR-2011-1209

Irvine, S., Thorpe, K., McDonald, P., Lunn, J., \& Sumsion, J., (2016). Money, love and identity: Initial findings from the National ECEC Workforce Study. Summary report from the national ECEC Workforce Development Policy Workshop, Brisbane, Queensland: QUT. https://eprints.qut.edu.au/101622/1/Brief_report_ECEC_ Workforce_Development_Policy_Workshop_final.pdf

Kilgallon, P., Maloney, C., \& Lock, G. (2008). Early childhood teachers' sustainment in the classroom. Australian Journal of Teacher Education, 33(2), 41-54. https://doi.org/10.14221/ajte.2008v $33 \mathrm{n} 2.3$

Klassen, R. M., \& Chiu, M. M. (2011). The occupational commitment and intention to quit of practicing and pre-service teachers: Influence of self-efficacy, job stress, and teaching context. Contemporary Educational Psychology, 36(2), 114-129. https://doi.org/10. 1016/j.cedpsych.2011.01.002

Klassen, R., Wilson, E., Siu, A. F. Y., Hannok, W., Wong, M. W., Wongsri, N., Jansem, A., et al. (2013). Preservice teachers' work stress, self-efficacy, and occupational commitment in four countries. European Journal of Psychology of Education, 28(4), 12891309. https://doi.org/10.1007/s10212-012-0166-x
Kokkinos, C. M. (2007). Job stressors, personality and burnout in primary school teachers. British Journal of Educational Psychology, 77(1), 229-243. https://doi.org/10.1348/000709905X90344

Lipscomb, S. T., Hatfield, B., Goka-Dubose, E., Lewis, H., \& Fisher, P. A. (2021). Impacts of roots of resilience professional development for early childhood teachers on young children's protective factors. Early Childhood Research Quarterly, 56, 1-14. https:// doi.org/10.1016/j.ecresq.2021.02.002

Lipscomb, S. T., Schmitt, S. A., Pratt, M., Acock, A., \& Pears, K. C. (2014). Living in non-parental care moderates effects of prekindergarten experiences on externalizing behavior problems in school. Children and Youth Services Review, 40, 41-50. https:// doi.org/10.1016/j.childyouth.2014.02.006

Liu, J. J. W., Reed, M., \& Girard, T. A. (2017). Advancing resilience: An integrative, multi-system model of resilience. Personality and Individual Differences, 111, 111-118. https://doi.org/10.1016/j. paid.2017.02.007

Mashburn, A. J., Hamre, B. K., Downer, J. T., \& Pianta, R. C. (2006). Teacher and classroom characteristics associated with teachers' ratings of prekindergartners' relationships and behaviors. Journal of Psychoeducational Assessment, 24(4), 367-380. https://doi.org/ 10.1177/0734282906290594

Masten, A. S. (2018). Resilience theory and research on children and families: Past, present, and promise: Resilience theory and research. Journal of Family Theory \& Review, 10(1), 12-31. https://doi.org/10.1111/jftr.12255

McGinty, A. S., Justice, L., \& Rimm-Kaufman, S. E. (2008). Sense of school community for preschool teachers serving at-risk children. Early Education and Development, 19(2), 361-384. https://doi. org/10.1080/10409280801964036

Minghui, L., Lei, H., \& Potměšilc, M. (2018). Teacher efficacy, work engagement, and social support among Chinese special education school teachers. Frontiers in Psychology, 9, 1-8. https://doi.org/ 10.3389/fpsyg.2018.00648

Nislin, M., Sajaniemi, N., Sims, M., Suhonen, E., Maldonado, E. F., Hyttinen, S., \& Hirvonen, A. (2016). Occupational well-being and stress among early childhood professionals: The use of an innovative strategy to measure stress reactivity in the workplace. Open Review of Educational Research, 3(1), 1-17. https://doi.org/ 10.1080/23265507.2015.1128352

Oberle, E., \& Schonert-Reichl, K. A. (2016). Stress contagion in the classroom? The link between classroom teacher burnout and morning cortisol in elementary school students. Social Science \& Medicine, 159, 30-37. https://doi.org/10.1016/j.socscimed. 2016.04.031

Pas, E. T., Bradshaw, C. P., \& Hershfeldt, P. A. (2012). Teacher-and school-level predictors of teacher efficacy and burnout: Identifying potential areas for support. Journal of school Psychology, 50(1), 129-145. https://doi.org/10.1016/j.jsp.2011.07.003

Pepe, A., Addimando, L., Dagdukee, J., \& Veronese, G. (2019). Psychological distress, job satisfaction, and work engagement among Palestinian teachers: A cross-sectional study. The Lancet, 393, S40. https://doi.org/10.1016/S0140-6736(19)30626-9

Reynolds, A. J., Ou, S.-R., Mondi, C. F., \& Hayakawa, M. (2017). Processes of early childhood interventions to adult well-being. Child Development, 88(2), 378-387. https://doi.org/10.1111/cdev.12733

Roberts, A. M., Gallagher, K. C., Daro, A. M., Iruka, I. U., \& Sarver, S. L. (2019). Workforce well-being: personal and workplace contributions to early educators' depression across settings. Journal of Applied Developmental Psychology, 61, 4-12. https://doi.org/ 10.1016/j.appdev.2017.09.007

Roberts, A. M., LoCasale-Crouch, J., Hamre, B., \& Jamil, F. (2020). Preschool teachers' self-efficacy, burnout, and stress in online professional development: A mixed methods approach to understand change. Journal of Early Childhood Teacher Education, 41, 262-283. https://doi.org/10.1080/10901027.2019.1638851 
Schaufeli, W. B., \& Bakker, A. B. (2004). Job demands, job resources, and their relationship with burnout and engagement: A multi-sample study. Journal of Organizational Behavior, 25(3), 293-315. https://doi.org/10.1002/job.248

Schaufeli, W. B., Salanova, M., González-romá, V., \& Bakker, A. B. (2002). The measurement of engagement and burnout: A two sample confirmatory factor analytic approach. Journal of Happiness Studies, 3(1), 71-92. https://doi.org/10.1023/A:1015630930326

Schroeter, M. K., Strolin-Goltzman, J., Suter, J., Werrbach, M., Hayden-West, K., Wilkins, Z., Rock, J., et al. (2015). Foster youth perceptions on educational well-being. Families in Society, 96(4), 227-233. https://doi.org/10.1606/1044-3894.2015.96.30

Shimazu, A., \& Schaufeli, W. B. (2008). Work engagement: An emerging concept in occupational health psychology. Bioscience Trends, 2(1), 2. https://doi.org/10.1080/02678370802393649

Skaalvik, E. M., \& Skaalvik, S. (2014). Teacher self-efficacy and perceived autonomy: Relations with teacher engagement, job satisfaction, and emotional exhaustion. Psychological Reports, 114(1), 68-77. https://doi.org/10.2466/14.02.PR0.114k14w0

Soliday Hong, S. L., Howes, C., Marcella, J., Zucker, E., \& Huang, Y. (2015). Quality Rating and Improvement Systems: Validation of a local implementation in LA County and children's schoolreadiness. Early Childhood Research Quarterly, 30, 227-240. https://doi.org/10.1016/j.ecresq.2014.05.001

StataCorp. (2015). Stata Statistical Software: Release 14. StataCorp LP.

Strolin-Goltzman, J., Woodhouse, V., Suter, J., \& Werrbach, M. (2016). A mixed method study on educational well-being and resilience among youth in foster care. Children and Youth Services Review, 70, 30-36. https://doi.org/10.1016/j.childyouth.2016.08.014

Tayama, J., Yoshida, Y., Iwanaga, R., Tokunaga, A., Tanaka, G., Imamura, A., Shirabe, S., et al. (2018). Factors associated with preschool workers' willingness to continue working. Medicine, 97(49), 1-6. https://doi.org/10.1097/MD.0000000000013530

Totenhagen, C. J., Hawkins, S. A., Casper, D. M., Bosch, L. A., Hawkey, K. R., \& Borden, L. M. (2016). Retaining early childhood education workers: A review of the empirical literature. Journal of Research in Childhood Education, 30(4), 585-599. https://doi.org/10.1080/02568543.2016.1214652

Tschannen-Moran, M., \& Hoy, A. W. (2001). Teacher efficacy: Capturing an elusive construct. Teaching and Teacher Education, 17(7), 783-805. https://doi.org/10.1016/S0742-051X(01)00036-1

Tschannen-Moran, M., Hoy, A. W., \& Hoy, W. K. (1998). Teacher efficacy: Its meaning and measure. Review of Educational Research, 68(2), 202-248. https://doi.org/10.3102/00346543068002202

Tsouloupas, C., Carson, R., Matthews, R., Grawitch, M., \& Barber, L. (2010). Exploring the association between teachers' perceived student misbehaviour and emotional exhaustion: The importance of teacher efficacy beliefs and emotion regulation. Educational Psychology, 30, 173-189. https://doi.org/10.1080/0144341090 3494460

Ungar, M., \& Liebenberg, L. (2011). Assessing resilience across cultures using mixed methods: Construction of the child and youth resilience measure. Journal of Mixed Methods Research, 5(2), 126-149. https://doi.org/10.1177/1558689811400607

Vandell, D. L., Belsky, J., Burchinal, M., Vandergrift, N., \& Steinberg, L. (2010). Do effects of early child care extend to age 15 years? Results from the NICHD Study of Early Child Care and Youth Development. Child Development, 81(3), 737-756. https://doi. org/10.1111/j.1467-8624.2010.01431.x

Von Suchodoletz, A., Faiza, J., Larsen, R. A. A. A., \& Hamre, B. K. (2018). Personal and contextual factors associated with growth in preschool teachers' self-efficacy beliefs during a longitudinal professional development study. Teaching and Teacher Education, 75, 278-289. https://doi.org/10.1016/j.tate.2018.07.009

Wagner, B., \& French, L. (2010). Motivation, work satisfaction, and teacher change among early childhood teachers. Journal of Research in Childhood Education, 24(2), 152-171. https://doi. org/10.1080/02568541003635268

Whitaker, R. C., Dearth-Wesley, T., \& Gooze, R. A. (2015). Workplace stress and the quality of teacher-children relationships in Head Start. Early Childhood Research Quarterly, 30, 57-69. https:// doi.org/10.1016/j.ecresq.2014.08.008

Whitebook, M., King, E., Philipp, G., \& Sakai, L. (2016). Teachers' voices: Work environment conditions that impact teacher practice and program quality. Center for the Study of Child Care Employment, University of California, Berkeley

Whitebook, M., Mclean, C., Austin, L. J. E., \& Edwards, B. (2018). Early Childhood Workforce Index. Center for the Study of Child Care Employment, University of California, Berkeley: https:// cscce.berkeley.edu/early-childhood-workforce-2018-index/

Xanthopoulou, D., Bakker, A. B., Demerouti, E., \& Schaufeli, W. B. (2007). The role of personal resources in the Job DemandsResources model. International Journal of Stress Management, 14(2), 121-141. https://doi.org/10.1037/1072-5245.14.2.121

Yoon, J. S. (2002). Teacher characteristics as predictors of teacherstudent relationships: Stress, negative affect, and self-efficacy. Social Behavior and Personality: An International Journal, 30(5), 485-494. https://doi.org/10.2224/sbp.2002.30.5.485

Publisher's Note Springer Nature remains neutral with regard to jurisdictional claims in published maps and institutional affiliations. 